\title{
Correction to: Cytochrome P450 1A1 enhances inflammatory responses and impedes phagocytosis of bacteria in macrophages during sepsis
}

Li-Xing Tian' ${ }^{1}$, Xin Tang ${ }^{1}$, Jun-Yu Zhu' ${ }^{1}$, Li Luo ${ }^{1}$, Xiao-Yuan Ma', Shao-Wen Cheng ${ }^{2}$, Wei Zhang ${ }^{3}$, Wan-Qi Tang ${ }^{1}$, Wei Ma', Xue Yang ${ }^{1}$, Chuan-Zhu Lv ${ }^{2}$ and Hua-Ping Liang ${ }^{1 *}$

\section{Correction to: Cell Commun Signal (2020) 18:70 \\ https://doi.org/10.1186/s12964-020-0523-3}

Following publication of the original article [1], the authors identified that four western blot bands in Figs. 1, 2 and Additional file 1: Figure S4 were incorrect. The correct images are presented in this correction article and the corrections to these bands do not change the conclusion to the paper. The authors apologize for the error.

\section{Supplementary information}

Supplementary information accompanies this paper at https://doi.org/10. 1186/s12964-020-00597-8.

Additional file 1: Figure S4. Validation of the NF-KB signalling pathway and different MAPK signalling pathways in LPS-stimulated CYP1A1/RAW and NC/RAW.
Published online: 18 May 2020

\section{Reference}

1. Tian L, Tang X, Zhu J, et al. Cytochrome P450 1A1 enhances inflammatory responses and impedes phagocytosis of bacteria in macrophages during sepsis. Cell Commun Signal. 2020;18:70 https://doi.org/10.1186/s12964-0200523-3.

\section{Author details}

'State Key Laboratory of Trauma, Burns and Combined Injury, Department of Wound Infection and Drug, Daping Hospital, Army Medical University, Yuzhong District, Chongqing, China. ${ }^{2}$ Trauma Center, The First Affiliated Hospital of Hainan Medical University, Haikou, China. ${ }^{3}$ Emergency and Trauma College of Hainan Medical University, Haikou, China.

The original article can be found online at https://doi.org/10.1186/s12964020-0523-3.

* Correspondence: 13638356728@163.com

'State Key Laboratory of Trauma, Burns and Combined Injury, Department of Wound Infection and Drug, Daping Hospital, Army Medical University, Yuzhong District, Chongqing, China

Full list of author information is available at the end of the article

(c) The Author(s). 2020 Open Access This article is licensed under a Creative Commons Attribution 4.0 International License, which permits use, sharing, adaptation, distribution and reproduction in any medium or format, as long as you give appropriate credit to the original author(s) and the source, provide a link to the Creative Commons licence, and indicate if changes were made. The images or other third party material in this article are included in the article's Creative Commons licence, unless indicated otherwise in a credit line to the material. If material is not included in the article's Creative Commons licence and your intended use is not permitted by statutory regulation or exceeds the permitted use, you will need to obtain permission directly from the copyright holder. To view a copy of this licence, visit http://creativecommons.org/licenses/by/4.0/ The Creative Commons Public Domain Dedication waiver (http://creativecommons.org/publicdomain/zero/1.0/) applies to the data made available in this article, unless otherwise stated in a credit line to the data. 

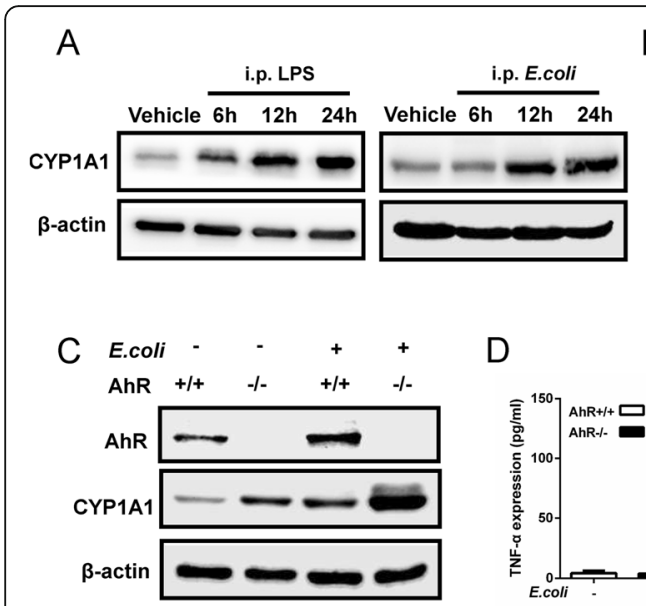

$\mathrm{B}$

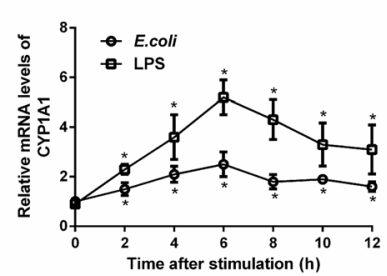

D

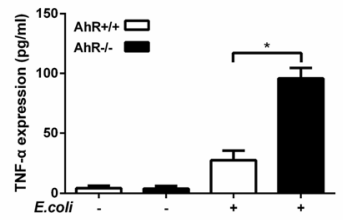

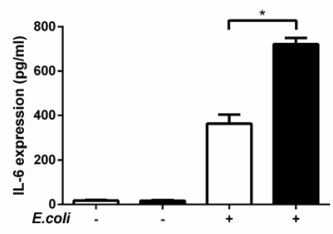

E

Fig. 1 CYP1A1 is upregulated in PMs of septic mice. a Mice were intraperitoneally injected with vehicle (isopyknic PBS), LPS (20 mg/kg) or E. coll $\left(1.2 \times 10^{11} \mathrm{CFUs} / \mathrm{kg}\right.$, CFUs, colony forming units). PMs were extracted at the indicated times and subjected to western blotting analysis of CYP1A1 protein levels. b PMs isolated from WT mice were treated with vehicle, LPS $(10 \mu \mathrm{g} / \mathrm{ml})$ or heat-killed E. coli (MOls $=10$, MOls, multiplicity of infections) for the indicated times. CYP1A1 mRNA expression was quantified by qRT-PCR. Expression levels of CYP1A1 protein were detected by western blotting. c-e $\mathrm{AhR}^{-/-}$and WT mice were intraperitoneally injected with vehicle or E.coli. After $12 \mathrm{~h}$ treatment, PMs and PLFs were extracted and subjected to analysis of AhR and CYP1A1 protein expression levels (a), pro-inflammatory cytokines expression levels (b) and PMs count (c). Data are mean \pm SEM of three independent experiments. Results were compared by one-way ANOVA. ${ }^{*} p<0.05$. NS, no statistical difference 


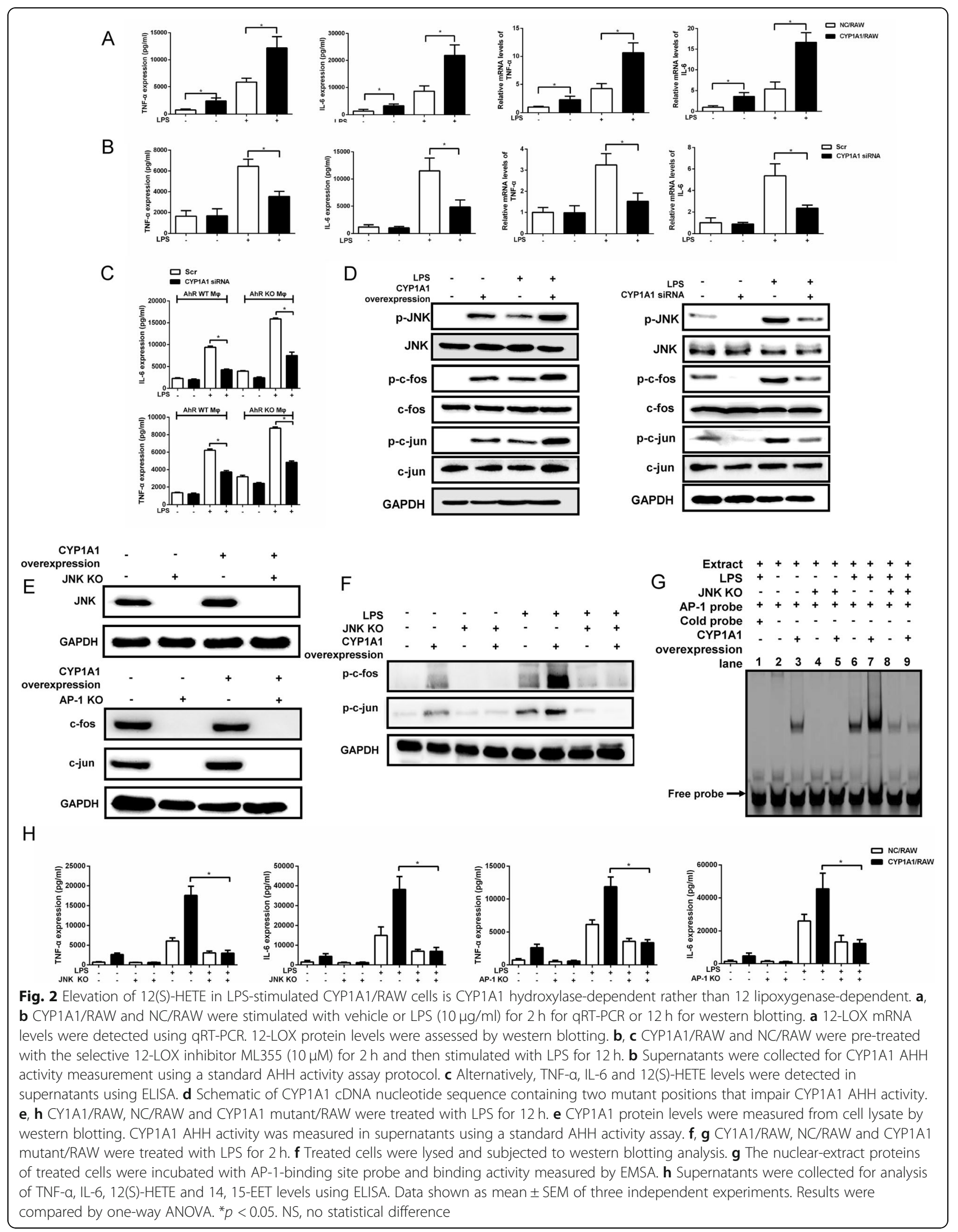

